\title{
Woody medicinal plants of the caatinga in the state of Pernambuco (Northeast Brazil)
}

\author{
Ana Carolina Oliveira da Silva ${ }^{1}$ and Ulysses Paulino de Albuquerque ${ }^{1,2}$
}

Received: March 10, 2003; Accepted: July 13, 2004

\begin{abstract}
RESUMO - (Plantas medicinais arbóreas da caatinga no Estado de Pernambuco (Nordeste do Brasil)). Com o objetivo de analisar, a partir de uma perspectiva etnobotânica, a importância relativa das espécies arbóreas medicinais da caatinga pernambucana, foram selecionados trabalhos florísticos e fitossociológicos realizados em seis áreas no Estado de Pernambuco. Para análise dos dados, foram selecionadas apenas as espécies identificadas até o nível de espécie e para cada uma levantou-se informações medicinais disponíveis na literatura. Para cada espécie calculou-se a importância relativa. Das 57 espécies arbóreas, 22 possuem indicação terapêutica, sendo Anacardium occidentale L., Tabebuia impetiginosa (Mart. ex DC) Standley, Schinopsis brasiliensis Engl. e Myracrodruon urundeuva (Engl.) Fr. All., as espécies com os maiores valores de Importância Relativa. A análise de correlação evidenciou que a importância relativa das espécies encontra-se negativamente correlacionada com a Densidade e Freqüência Relativas ( $<<0,05)$. As espécies mais importantes, do ponto de vista etnobotânico, são também as mais vulneráveis devido à exploração sistemática que vêm sofrendo. Schinopsis brasiliensis e Myracrodruon urundeuva constam na lista de espécies ameaçadas de extinção e merecem atenção especial no desenvolvimento de técnicas de manejo sustentável, visando retorno econômico e garantindo a conservação. São necessários estudos detalhados que analisem as peculiaridades de cada região, tanto do ponto de vista florístico quanto etnobotânico, uma vez que cada área parece ter sua própria flora arbórea medicinal, como sugerido nas análises de agrupamento.
\end{abstract}

Palavras-chave: Florestas tropicais secas, plantas medicinais, etnobotânica, florística, fitossociologia

ABSTRACT-(Woody medicinal plants of the caatinga in the state of Pernambuco (Northeast Brazil)). Floristic and phytosociological studies undertaken in six areas of the state of Pernambuco were selected with the aim of analyzing the Relative Importance of the woody medicinal plant species of Pernambuco's caating a from an ethnobotanical perspective. For the data analysis, only those identified up to the species level were selected and information on medicinal properties was obtained for each one from the literature. The Relative Importance was calculated for each species. From the 57 woody species, 22 had therapeutic indications; from these, Anacardium occidentale L., Tabebuia impetiginosa (Mart. ex DC) Standley, Schinopsis brasiliensis Engl., and Myracrodruon urundeuva (Engl.) Fr. All. had the greatest values of Relative Importance. The correlation analysis made clear that the Relative Importance of the species is negatively correlated with the Density and Relative Frequency $(\mathrm{p}<0.05)$. The most important species, in the ethnobotanical point view, are the most vulnerable, possible due to the systematic exploration they have been suffering. Schinopsis brasiliensis and Myracrodruon urundeuva are listed as endangered species and deserve special attention in the development of techniques of sustainable management, where both economic return and species conservation must be guaranteed. In depth studies that take into consideration each region's characteristics are necessary both from a floristic perspective and considering medicinal aspects, since each area seems to have its own woody medicinal flora, as suggested in the cluster analysis.

Key words: Tropical dry forests, medicinal plants, ethnobotany, floristic, phytosociology

\section{Introduction}

The caatinga is a dry forest, green only during rainy periods, with spiny shrubs, and adapted to the more sterile soils. Caatinga vegetation comprises an area of approximately $734,478 \mathrm{~km}^{2}$, including parts of the states of Piauí, Ceará, Rio Grande do Norte, Paraíba, Pernambuco, Alagoas, Sergipe, Bahia, and Minas Gerais. This biome is dominated by one of the few types of vegetation whose distribution is totally restricted to Brazil (Hueck 1972; Ferri 1980), but little is known yet about its floristic diversity. Some studies undertaken (Agra 1999; Lima 1999; Albuquerque et al. 2005) reveal species with great potential as forage, food, medicine and timber. A great diversity of forms of caatinga is found, distinguished by the geomorphological landscape and in the geologic characteristics were they occur. Floristic and

\footnotetext{
1 Universidade Federal Rural de Pernambuco, Departamento de Biologia, Área de Botânica, Laboratório de Etnobotânica Aplicada, Rua Dom Manoel de Medeiros s/n, Dois Irmãos, CEP 52171-900, Recife, PE, Brasil (www.ufrpe.br/lea)

2 Corresponding Author: upa@ufrpe.br
} 
phytosociological studies founded expressive variation in diversity and structure in different geomorphological conditions (Oliveira et al. 1997; Rodal et al. 1998; Araújo \& Martins 1999).

In relation to medicinal plants, there are few studies that enable a wider vision of the great diversity of species used by the population for therapeutic purposes. Much of the traditional knowledge about plants, especially medicinal plants, is being lost with time, either because of the lack of studies or by the inadequate use of plant resources. Some plant species of the caatinga suffer great pressure due to the absence of sustainable management techniques for their use, and threaten to disappear from the native flora. According to Lima (1999), in addition to the innumerable reasons for the conservation of the caatingas (based on the preservation of genetic diversity and on its importance for other natural resources such as soil, water, and fauna), the extractivist value of this ecosystem is especially crucial in regions where agricultural activities (such as constant fires, soil use, and wood extraction for different purposes) are common.

This study aims to analyze, from an ethnobotanical perspective, the relative importance of some known medicinal species that occur in the caatinga of Pernambuco by relating this data with some phytosociological parameters. Were used here plant surveys conducted in six different localities: Ibimirim, Buíque, Caruaru, Poço do Ferro (municipality of Floresta), Baixa do Favaleiro (municipality of Floresta), and Custódia. Ibimirim, for example, was selected because it represents the typical flora and vegetation from Pernambuco's sedimentary plateaus; and Buíque because floristically is most similar to the spiny caducifolious caatinga vegetation, found in areas of sandy substrates, due to a group of species widely distributed among that type of vegetation. The other areas are also important considering the variation in the vegetation structure and physical environment. At moment, 322-339 woody species have been registered for the caatinga flora (Sampaio 1995; Rodal \& Melo 1999). The selected areas have about 23-192 plant species (including woody).

\section{Material and methods}

Study sites - This work started with a survey of floristic and phytosociological studies undertaken in the state of Pernambuco. Studies were selected from six different areas of the state. These plant surveys represented good-published information available on woody plant species composition at local level (Tab. 1).

Data Analysis - Only the trees identified up to the species level were selected for the data analysis; for each one the Relative Density (RD), Relative Frequency (RF), Relative Dominance (RDO), and the Importance Value Index (VI) data were used. With the original list obtained, information was compiled about the medicinal uses of each species using the available literature (for example: Braga 1960; Di Stasi et al. 1989; Agra 1996; Albuquerque et al. 2005; Almeida \& Albuquerque 2002; Albuquerque \& Andrade, 2002a,b), as well as web sites.

For each plant species, the Relative Importance was calculated (Bennett \& Prance 2000), with the exception of Cedrela odorata L. and Aspidospema pyrifolium Mart., for which only a reference to their medicinal properties was found, without a precise indication of the types of uses. In this calculation, "2" is the greatest value that a species can attain:

$$
\mathrm{RI}=\mathrm{NCS}+\mathrm{NP} \text {, where: }
$$

$\mathrm{RI}=$ relative importance;

$\mathrm{NCS}=$ number of corporeal systems. It is given by the number of corporeal systems treated by a species (NSCS) over the total number of corporeal systems treated by the most versatile species (NSCSV).

$$
\mathrm{NCS}=\frac{\mathrm{NSCS}}{\mathrm{NSCS} V}
$$

$\mathrm{NP}=$ number of properties attributed to a specific species (NPS) over the total number of properties attributed to the most versatile species (NPSV):

$\mathrm{NP}=\frac{\mathrm{NPS}}{\text { NPS } V}$

From the list of species, two presence or absence matrices were created: one considering all the woody species and the other solely considering the species for which medicinal properties were reported. In the next step the similarity between each area was calculated (Jaccard's coefficient). The cluster analyses were processed by the UPGMA method (Unweighted Pair Group Method with Arithmetic Mean) using the NTSYS-PC, version 1.8 (Rohlf 1993).

Linear correlation analysis was performed using the software Statistica 5.0. The Relative Importance of each species was used in this analysis, as well as the phytosociological analysis, where it was attempted to verify an association between the different variables. 
Table 1. Main characteristic of the six areas of caatinga vegetation analysed in this study. BSD = basal stem diameter $(\mathrm{cm})$.

\begin{tabular}{|c|c|c|c|c|c|c|}
\hline Area & Sample size & $\begin{array}{l}\text { Sampling } \\
\text { criteria }\end{array}$ & $\begin{array}{c}\text { Location } \\
\text { (Lat. S, Long. W) }\end{array}$ & $\begin{array}{l}\text { Elevation } \\
\quad(\mathrm{m})\end{array}$ & $\begin{array}{c}\text { Rainfall } \\
\left(\mathrm{mm}_{\text {year }}{ }^{-1}\right)\end{array}$ & Source of data \\
\hline Buíque & 1 ha & $3 \mathrm{BSD}$ & $8^{\circ} 35^{\prime}-37^{\circ} 15^{\prime}$ & 835 & 600 & Gomes (1999) \\
\hline $\begin{array}{l}\text { Baixa do Faveleiro } \\
\text { (municipality of Floresta) }\end{array}$ & 1 ha & $5 \mathrm{BSD}$ & $\begin{array}{c}\text { Between } \\
8^{\circ} 30^{\prime} \text { and } 8^{\circ} 37^{\prime} \\
38^{\circ} 00^{\prime} \text { and } 38^{\circ} 17^{\prime}\end{array}$ & 470 & 585 & Araújo et al. (1995) \\
\hline Caruaru & 0.6 ha & $3 \mathrm{BSD}$ & $8^{\circ} 14^{\prime}-35^{\circ} 55^{\prime}$ & 537 & 694 & Alcoforado Filho et al. (2003) \\
\hline Ibimirim & $\begin{array}{c}? \\
\text { (floristic) }\end{array}$ & $\begin{array}{l}\text { All woody } \\
\text { species }\end{array}$ & $8^{\circ} 39^{\prime}-37^{\circ} 35^{\prime}$ & 600 & 631 & Rodal et al. (1999) \\
\hline $\begin{array}{l}\text { Poço do Ferro } \\
\text { (municipality of Floresta) }\end{array}$ & 1 ha & $5 \mathrm{BSD}$ & $\begin{array}{c}\text { Between } \\
8^{\circ} 30^{\prime} \text { and } 8^{\circ} 37^{\prime} \\
38^{\circ} 00^{\prime} \text { and } 38^{\circ} 17^{\prime}\end{array}$ & 470 & 585 & Araújo et al. (1995) \\
\hline $\begin{array}{l}\text { Samambaia } \\
\text { (municipality of Custódia) }\end{array}$ & 1 ha & $5 \mathrm{BSD}$ & $8^{\circ} 06^{\prime}-37^{\circ} 19^{\prime}$ & 500 & 574 & Araújo et al. (1995) \\
\hline
\end{tabular}

\section{Results and discussion}

From the six areas, 57 woody species were selected, distributed among 22 families and 46 genera. The cluster analysis performed with the UPGMA method indicates that there was a greater similarity between Poço do Ferro (A3) and Baixa do Faveleiro (A4), due to the presence of eight species in common (Myracrodruon urundeuva, Aspidosperma pyrifolium, Bursera leptophloeos, Bauhinia cheilanta, Caesalpinia pyramidalis, Jatropha mollissima, Anadenanthera colubrina var. cebil, and Allophylus quercifolius) (Fig. 1). The area located in the municipality of Buíque shows very little similarity, maybe because it is a transitional type of vegetation. The similarity of the arboreal flora between these areas can be attributed to the fact that both are located in the same municipality (Floresta). The geographic proximity is considered an important element in the determination of floristic similarity between xerophile

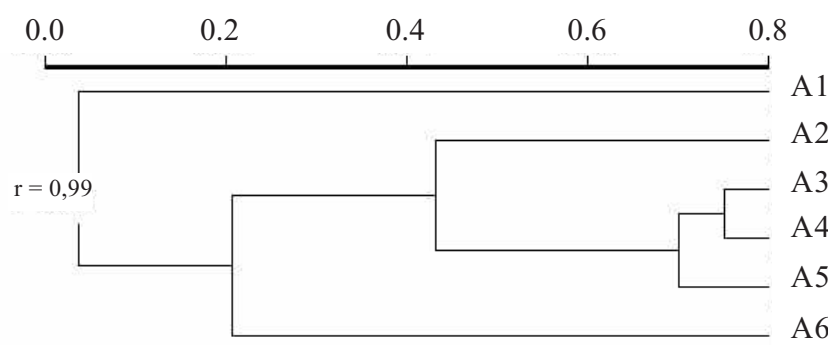

Figure 1. Dendrogram performed on Jaccard similarity matrix (presence-absence data) of six areas of caatinga considering all woody plant species (57). A1 (Buíque), A2 (Caruaru), A3 (Poço do Ferro, municipality of Floresta), A4 (Baixa do Faveleiro, municipality of Floresta), A5 (Samambaia, municipality of Custódia), and A6 (Ibimirim). communities of the northeastern semi-arid, which justifies the results (Figueirêdo et al. 2000).

The family that stood out the most in the survey was Mimosaceae, with 33 species and 7 genera, followed by Caesalpiniaceae ( 9 and 6), Euphorbiaceae (8 and 7), Anacardiaceae (4 and 4), and Fabaceae (4 and 3). The remaining families were represented by one to three species (Tab. 2). Few studies have revealed the approximate number of woody species of the caatinga, but Rodal \& Melo (1999), in a preliminary study about these species, listed a total of 322 species, distributed among 46 families, 164 genera, and 26 orders. Sampaio (1995), in a review of 38 published studies, found a total of 339 woody species from 161 genera and 48 families. According to the author, the families or subfamilies with the greatest number of species are: Caesalpiniaceae (45 spp.), Mimosaceae (43 spp.), Euphorbiaceae (32 spp.), Fabaceae (30 spp.), and Cactaceae (14 spp.); and the genera were Cassia (14 spp.), Mimosa (10 spp.), and Pithecellobium (9 spp.).

Among the representatives of the families with a greater number of species, Caesalpinia pyramidalis (Caesalpiniaceae), Bauhinia cheilanta (Caesalpiniaceae), and Piptadenia obliqua (Mimosaceae) stood out due to their high Relative Frequency values. The species Caesalpinia pyramidalis (Caesalpiniaceae) is the only one that occurs in five of the six areas studied, and is also the species with the greatest values of VI for these areas (see Tab. 3 and 4). This species is referred to as having one of the greatest densities in different surveys (Sampaio 1995). Other species, such as Bursera leptophloeos (Burseraceae), Bauhinia 
Table 2. List of woody species selected from six areas of caatinga in the state of Pernambuco. A1 (Buíque), A2 (Caruaru), A3 (Poço do Ferro, municipality of Floresta), A4 (Baixa do Faveleiro, municipality of Floresta), A5 (Samambaia, municipality of Custódia), and A6 (Ibimirim).

\begin{tabular}{|c|c|c|c|c|c|c|}
\hline \multirow[t]{2}{*}{ Species/Family } & \multicolumn{6}{|c|}{ Areas } \\
\hline & A 1 & A2 & A3 & A4 & A5 & A6 \\
\hline \multicolumn{7}{|l|}{ ANACARDIACEAE } \\
\hline Anacardium occidentale L. & - & $\mathrm{X}$ & - & - & - & - \\
\hline Myracrodruon urundeuva (Engl.) Fr. All. & - & $\mathrm{X}$ & - & $\mathrm{X}$ & $\mathrm{X}$ & - \\
\hline Schinopsis brasiliensis Engl. & - & $\mathrm{X}$ & $\mathrm{X}$ & - & $\mathrm{X}$ & $\mathrm{X}$ \\
\hline Spondias tuberosa Arr. Cam. & - & - & - & $\mathrm{X}$ & - & - \\
\hline \multicolumn{7}{|l|}{ ANNONACEAE } \\
\hline Rollinia leptopetala (R.E. Fries) Safford & $\mathrm{X}$ & - & - & - & - & $\mathrm{X}$ \\
\hline \multicolumn{7}{|l|}{ APOCYNACEAE } \\
\hline Aspidosperma pyrifolium Mart. & - & - & $\mathrm{X}$ & $\mathrm{X}$ & $\mathrm{X}$ & $\mathrm{X}$ \\
\hline \multicolumn{7}{|l|}{ BIGNONIACEAE } \\
\hline Tabebuia impetiginosa (Mart. ex DC.) Standley & $\mathrm{X}$ & - & - & - & $\mathrm{X}$ & - \\
\hline \multicolumn{7}{|l|}{ BOMBACACEAE } \\
\hline Chorisia glaziovii (O. Kuntze) E. Santos & - & $\mathrm{X}$ & - & - & - & - \\
\hline \multicolumn{7}{|l|}{ BURSERACEAE } \\
\hline Bursera leptophloeos (Mart.) Gillet. & - & $\mathrm{X}$ & $\mathrm{X}$ & $\mathrm{X}$ & $\mathrm{X}$ & $\mathrm{X}$ \\
\hline \multicolumn{7}{|l|}{ CAESALPINIACEAE } \\
\hline Bauhinia cheilanta (Bong.) Steud. & - & $\mathrm{X}$ & $\mathrm{X}$ & $\mathrm{X}$ & $\mathrm{X}$ & - \\
\hline Caesalpinia ferrea Mart. ex Tul. & & & & & & $\mathrm{X}$ \\
\hline C. mycrophylla Mart. ex Tul. & $\mathrm{X}$ & - & $\mathrm{X}$ & - & - & $\mathrm{X}$ \\
\hline C. pyramidalis Tul. & & $\mathrm{X}$ & $\mathrm{X}$ & $\mathrm{X}$ & $\mathrm{X}$ & $\mathrm{X}$ \\
\hline Hymenaea courbaril L. & $\mathrm{X}$ & - & - & - & - & - \\
\hline Peltogyne pauciflora Benth. & $\mathrm{X}$ & - & - & - & - & - \\
\hline Poeppigia procera Pres1 & - & - & - & - & - & $\mathrm{X}$ \\
\hline Senna cana (Nees \& Mart.) H.S. Irwin \& Barneby & - & $\mathrm{X}$ & - & - & - & - \\
\hline S. rizzini H.S. Irwin \& Barneby & $\mathrm{X}$ & - & - & - & - & $\mathrm{X}$ \\
\hline \multicolumn{7}{|l|}{ CAPPARACEAE } \\
\hline Capparis flexuosa (L.) L. & - & $\mathrm{X}$ & - & - & - & $\mathrm{X}$ \\
\hline \multicolumn{7}{|l|}{ CELASTRACEAE } \\
\hline Maytenus rigida Mart. & $\mathrm{X}$ & $\mathrm{X}$ & - & - & - & - \\
\hline \multicolumn{7}{|l|}{ CLUSIACEAE } \\
\hline Clusia paralicola $\mathrm{G}$. Mariz & - & $\mathrm{X}$ & - & - & - & - \\
\hline \multicolumn{7}{|l|}{ COMBRETACEAE } \\
\hline Buchenavia capitata (Vahl.) Eichl. & $\mathrm{X}$ & - & - & - & - & - \\
\hline \multicolumn{7}{|l|}{ EUPHORBIACEAE } \\
\hline Cnidoscolus obtusifolius Pohl & - & - & - & - & - & $\mathrm{X}$ \\
\hline C. quercifolius Pohl ex Baill. & - & - & - & - & - & $\mathrm{X}$ \\
\hline Euphorbia tirucalli L. & $\mathrm{X}$ & - & - & - & - & - \\
\hline Jatropha mollissima (Pohl) Baill & - & $\mathrm{X}$ & $\mathrm{X}$ & $\mathrm{X}$ & $\mathrm{X}$ & $\mathrm{X}$ \\
\hline Manihot dichotoma Ule & - & $\mathrm{X}$ & - & - & - & $\mathrm{X}$ \\
\hline Maprounea guianensis Aubl. & - & $\mathrm{X}$ & - & - & - & - \\
\hline Sapium lanceolatum (Muell. Arg.) Herber & - & $\mathrm{X}$ & - & - & - & - \\
\hline Sebastiania brasiliensis Spreng. & & & & & & \\
\hline \multicolumn{7}{|l|}{ FABACEAE } \\
\hline Amburana cearensis (Allemão) A.C. Sm. & - & - & - & - & $\mathrm{X}$ & - \\
\hline Dalbergia catingicola Harms & - & - & - & - & - & $\mathrm{X}$ \\
\hline D. cearensis Ducke & - & - & - & - & - & $\mathrm{X}$ \\
\hline Zornia dyphilla (L.) Pers. & - & - & - & - & - & $\mathrm{X}$ \\
\hline \multicolumn{7}{|l|}{ MELIACEAE } \\
\hline Cedrela odorata $\mathrm{L}$. & - & $\mathrm{X}$ & - & - & - & - \\
\hline \multicolumn{7}{|l|}{ MIMOSACEAE } \\
\hline Acacia glomerosa Benth. & - & $\mathrm{X}$ & - & - & - & - \\
\hline A. paniculata Willd. & - & $\mathrm{X}$ & - & - & - & - \\
\hline Anadenanthera colubrina (Vell.) Brenan. var. cebil (Griseb.) Altschul. & - & $\mathrm{X}$ & $\mathrm{X}$ & $\mathrm{X}$ & $\mathrm{X}$ & - \\
\hline
\end{tabular}


Table 2 (continuation)

Species/Family

Areas

\begin{tabular}{llllll}
\hline A1 & A2 & A3 & A4 & A5 & A6
\end{tabular}

Calliandra aeschynomenoides Benth.

Chloroleucon manguense (Jacq.) Briton \& Rose

Mimosa malacocentra Mart.

M. sensitiva $\mathrm{L}$.

M. tenuiflora (Willd.) Poir.

Parapiptadenia zehntneri (Harms) M.P. Lima \& H.C. Lima

Piptadenia obliqua (Pers.) J. F. Macbr.

P. stipulacea (Benth.) Ducke

P. viridiflora (Kunth) Benth.

NYCTAGINACEAE

Guapira laxa (Netto) Furla

G. noxia (Nett.) Lund.

POLYGONACEAE

Ruprechtia laxiflora Meissn.

RHAMNACEAE

Ziziphus joazeiro Mart.

RUBIACEAE

Alseis floribunda Schott

Coutarea hexandra (Jacq.) Schum.

Randia armata (SW.) DC.

RUTACEAE

Balfouradendron molle (Miquel) Pirani

SAPINDACEAE

Allophylus quercifolius Radlk.

SAPOTACEAE

Sideroxylon obtusifolium (Roem. \& Schult.) T.D. Penn.

\begin{tabular}{|c|c|c|c|c|}
\hline X & - & - & - & \\
\hline- & - & - & - & \\
\hline$X$ & - & - & - & \\
\hline$X$ & - & - & - & \\
\hline- & - & - & - & \\
\hline- & - & - & - & \\
\hline- & - & - & - & \\
\hline$X$ & - & - & - & \\
\hline$X$ & - & - & - & \\
\hline- & - & - & - & \\
\hline$X$ & - & - & - & \\
\hline$X$ & - & - & - & \\
\hline$X$ & - & - & - & \\
\hline$X$ & - & - & - & \\
\hline$X$ & - & - & - & \\
\hline$X$ & - & - & - & \\
\hline- & - & - & - & \\
\hline$X$ & - & $X$ & $\mathrm{X}$ & \\
\hline- & - & - & - & \\
\hline
\end{tabular}

cheilanta (Caesalpiniaceae), and Anadenanthera colubrina var. cebil (Mimosaceae) occurred in four areas, from which Bauhinia cheilanta has the greatest VI values (Tab. 3 and 4).

In relation to the medicinal importance, from the 57 selected species, 22 have therapeutic indication, which corresponds to $38.59 \%$ of the total number of species. Analyzing Figure 2, the areas with greatest floristic similarity from a medicinal point of view are Baixa do Faveleiro (A4) and Samambaia (Custódia municipality) (A5), with six species in common. When the dendrograms of Figures 1 and 2 are compared, it is verified that there is greater similarity between the areas when all of the arboreal components are considered, instead of when the elements with medicinal properties are isolated. This suggests how specific a medicinal flora seems to be even in areas very close geographically. At a local scale, close forest areas show more similarity in relation to their arboreal floristic composition and less similarity in relation to the medicinal component. How can this result be explained? Maybe the medicinal flora of each area is the result of the selective management undertaken by the local peoples. According to Balée (1988), in the case of the Amazonian Forest, what seems natural ("untouched") might have been manipulated by extinct human cultures. The author mentions several examples to support this hypothesis; one of them is that of the Brazil nut, which is largely used and is dominant in indigenous areas. In addition, it must be taken into consideration that the region of the caatinga is not floristically homogeneous. Classifying it is a difficult task, but with an ecological classification, Andrade-Lima (1981) recognized six units (with some representative genera), each one with one or several types, in a total of 12 types.

The families that stood out the most with a greater number of species known for their medicinal properties were Caesalpiniaceae (4 spp.), Mimosaceae (4 spp.), and Anacardiaceae (3 spp.). The most versatile species in relation to their uses, according to the Relative Importance (RI), were: Anacardium occidentale (2), Tabebuia impetiginosa (1.92), Schinopsis brasiliensis (1.24), and Myracrodruon urundeuva 
(1.1) (Tab. 5). Several species typical of the caatinga have an expressive local importance, but normally the most important are those of woody habit from which stalk barks are commonly used, according to Almeida $\&$ Albuquerque (2002) and Albuquerque \& Andrade (2002a,b). Usually, species like Anacardium occidentale and Myracrodruon urundeuva show up at the top of the lists of most important species in different ethnobotanical surveys. However, as documented by Almeida \& Albuquerque (2002) for some medicinal species used in Pernambuco, the Relative Importance of a species is independent of its origin or habit.

The species with the highest relative importance values generally have the lowest phytosociological parameter values. The correlation between Relative Importance with Density and Relative Frequency is significant despite the low values of the correlation coefficients, respectively $\mathrm{r}=-0.39$ and $-0.35(\mathrm{p}<0.05)$. This indicates that as the Relative Importance of a

Table 3. Woody species of the caatinga with medicinal importance selected from six study areas in the State of Pernambuco, Brazil and their respective phytosociological parameters of Relative Density (RD \%) and Relative Frequency (RF \%). A1 (Buíque), A2 (Caruaru), A3 (Poço do Ferro, municipality of Floresta), A4 (Baixa do Faveleiro, municipality of Floresta), A5 (Samambaia, municipality of Custódia), and A6 (Ibimirim). * Species not cited; ** Data not calculated by the authors.

\begin{tabular}{|c|c|c|c|c|c|c|c|c|c|c|c|c|}
\hline \multirow[t]{2}{*}{ Species/Family } & \multicolumn{6}{|c|}{$\mathrm{RD}$} & \multicolumn{6}{|c|}{$\mathrm{RF}$} \\
\hline & A1 & A2 & A3 & A4 & A5 & A6 & A1 & A2 & A3 & A4 & A5 & A6 \\
\hline \multicolumn{13}{|l|}{ ANACARDIACEAE } \\
\hline Anacardium occidentale L. & * & * & * & * & * & $* *$ & * & * & $*$ & * & $*$ & $* *$ \\
\hline $\begin{array}{l}\text { Myracrodruon urundeuva (Engl.) } \\
\text { Fr. All. }\end{array}$ & $*$ & 1.57 & $*$ & 0.5 & 3.5 & $* *$ & $*$ & 2.71 & $*$ & 0.6 & 4.6 & $* *$ \\
\hline Schinopsis brasiliensis Engl. & * & 2.23 & 0.2 & $*$ & 1.0 & $* *$ & * & 3.68 & 0.4 & * & 1.4 & $* *$ \\
\hline \multicolumn{13}{|l|}{ APOCYNACEAE } \\
\hline $\begin{array}{l}\text { Aspidosperma pyrifolium Mart. } \\
\text { BIGNONIACEAE }\end{array}$ & $*$ & $*$ & 4.0 & 2.5 & 0.8 & $* *$ & $*$ & $*$ & 5.3 & 2.8 & 1.1 & $* *$ \\
\hline $\begin{array}{l}\text { Tabebuia impetiginosa (Mart. ex DC.) } \\
\text { Standley }\end{array}$ & 1.00 & * & * & $*$ & 0.2 & $* *$ & 1.45 & * & $*$ & $*$ & 0.4 & $* *$ \\
\hline \multicolumn{13}{|l|}{ BURSERACEAE } \\
\hline $\begin{array}{l}\text { Bursera leptophloeos (Mart.) Gillet. } \\
\text { CAESALPINIACEAE }\end{array}$ & $*$ & 1.53 & 0.8 & 1.0 & 1.0 & $* *$ & $*$ & 3.29 & 1.1 & 1.3 & 1.4 & $* *$ \\
\hline Bauhinia cheilanta (Bong.) Steud. & $*$ & 10.72 & 1.2 & 12.2 & 1.2 & $* *$ & $*$ & 4.46 & 1.9 & 11.6 & 1.4 & $* *$ \\
\hline Caesalpinia ferrea Mart. ex Tul. & $*$ & $*$ & $*$ & * & $*$ & $* *$ & $*$ & * & $*$ & * & $*$ & $* *$ \\
\hline C. pyramidalis Tul. & * & 13.47 & 34.5 & 10.5 & 36.0 & $* *$ & $*$ & 5.63 & 28.7 & 10.4 & 28.0 & $* *$ \\
\hline Hymenaea courbaril L. & 0.25 & $*$ & $*$ & * & $*$ & $* *$ & 0.36 & $*$ & $*$ & $*$ & $*$ & $* *$ \\
\hline \multicolumn{13}{|l|}{ CAPPARACEAE } \\
\hline Capparis flexuosa (L.) L. & $*$ & 1.62 & $*$ & $*$ & $*$ & $* *$ & $*$ & 2.33 & $*$ & * & $*$ & $* *$ \\
\hline \multicolumn{13}{|l|}{ CELASTRACEAE } \\
\hline \multicolumn{12}{|l|}{ EUPHORBIACEAE } & $* *$ \\
\hline Euphorbia tirucalli L. & * & $*$ & $*$ & * & * & $* *$ & * & * & $*$ & * & $*$ & $* *$ \\
\hline $\begin{array}{l}\text { Jatropha mollissima (Pohl) Baill } \\
\text { FABACEAE }\end{array}$ & $*$ & 0.44 & 3.0 & 7.0 & 5.0 & $* *$ & $*$ & 1.16 & 4.2 & 6.9 & 6.0 & $* *$ \\
\hline $\begin{array}{l}\text { Amburana cearensis (Allemão) A.C. Sm. } \\
\text { MELIACEAE }\end{array}$ & * $*$ & $*$ & $*$ & * & 1.8 & $* *$ & * & * & $*$ & $*$ & 2.5 & $* *$ \\
\hline $\begin{array}{l}\text { Cedrela odorata } \mathrm{L} \text {. } \\
\text { MIMOSACEAE }\end{array}$ & $*$ & 0.04 & $*$ & * & $*$ & $* *$ & $*$ & 0.19 & $*$ & * & $*$ & $* *$ \\
\hline $\begin{array}{l}\text { Anadenanthera colubrina (Vell.) Brenan. } \\
\text { var. cebil (Griseb.) Altschul. }\end{array}$ & 1. * & 2.14 & 0.8 & 0.8 & 2.5 & $* *$ & * & 3.29 & 1.1 & 0.9 & 3.6 & $* *$ \\
\hline $\begin{array}{l}\text { Mimosa malacocentra } \text { Mart. } \\
M \text { tenuiflora (Willd) Poir }\end{array}$ & * & * & * & * & $*$ & $* *$ & * & * & $*$ & * & * & ** \\
\hline Piptadenia stipulacea (Benth.) Ducke & * & 3.59 & $*$ & * & * & $* *$ & * & 4.65 & $*$ & * & $*$ & $* *$ \\
\hline RHAMNACEAE & & & & & & & & & & & & \\
\hline $\begin{array}{l}\text { Ziziphus joazeiro Mart. } \\
\text { SAPOTACEAE }\end{array}$ & 0.25 & 0.09 & $*$ & $*$ & * & $* *$ & 0.36 & 0.39 & $*$ & $*$ & $*$ & $* *$ \\
\hline $\begin{array}{l}\text { Sideroxylon obtusifolium (Roem. \& } \\
\text { Schult.) T.D. Penn. }\end{array}$ & * & * & $*$ & $*$ & * & $* *$ & $*$ & $*$ & $*$ & $*$ & $*$ & $* *$ \\
\hline
\end{tabular}


species grows, its Density and Frequency diminish. The relation between the Relative Importance and the Importance Value Index is not significant. Albuquerque et al. (2005), in a regression analysis, verified that Frequency and Density are not significant variables to explain the Relative Importance of medicinal species in an area of caatinga in the state of Pernambuco. Phillips \& Gentry (1993) argue that there is a strong connection between ecological and usage data of a species and that the most common species are widely used. In this study an inverse relationship was found, in which the usage (RI) of a plant is negatively correlated with ecological data. It is noted, therefore, that this relationship varies from region to region, and studies are necessary in different localities. In addition, this study differs from those cited previously due to the fact that the authors collected the uses of the plants locally in order to calculate the Relative Importance, while here the total uses attributed for each of the species were considered.

Table 4. Woody species of medicinal importance from the caatinga selected from six studied in the state of Pernambuco, Brazil and their respective phytosociological parameters of Relative Dominance (RDO\%) and Importance Value Index (VI \%). A1 (Buíque), A2 (Caruaru), A3 (Poço do Ferro, municipality of Floresta), A4 (Baixa do Faveleiro, municipality of Floresta), A5 (Samambaia, municipality of Custódia), and A6 (Ibimirim). * Species not cited; ** Data not calculated by the authors.

\begin{tabular}{|c|c|c|c|c|c|c|c|c|c|c|c|c|}
\hline \multirow[t]{2}{*}{ Species/Family } & \multicolumn{6}{|c|}{ RDO } & \multicolumn{6}{|c|}{ VI } \\
\hline & A 1 & A2 & A3 & A4 & A5 & A6 & A1 & A2 & A3 & A4 & A5 & A6 \\
\hline \multicolumn{13}{|l|}{ ANACARDIACEAE } \\
\hline Anacardium occidentale L. & $*$ & $*$ & $*$ & $*$ & $*$ & $* *$ & $*$ & $*$ & $*$ & $*$ & $*$ & ** \\
\hline $\begin{array}{l}\text { Myracrodruon urundeuva (Engl.) } \\
\text { Fr. All. }\end{array}$ & $*$ & 3.69 & $*$ & 6.24 & 9.68 & $* *$ & $*$ & 7.97 & $*$ & 7.4 & 17.8 & $* *$ \\
\hline $\begin{array}{l}\text { Schinopsis brasiliensis Engl. } \\
\text { APOCYNACEAE }\end{array}$ & $*$ & 17.62 & 0.49 & $*$ & 1.03 & $* *$ & $*$ & 23.53 & 1.1 & $*$ & 3.4 & $* *$ \\
\hline $\begin{array}{l}\text { Aspidosperma pyrifolium Mart. } \\
\text { BIGNONIACEAE }\end{array}$ & $*$ & $*$ & 3.17 & 4.34 & 0.19 & $* *$ & $*$ & $*$ & 12.4 & 9.9 & 2.0 & $* *$ \\
\hline $\begin{array}{l}\text { Tabebuia impetiginosa (Mart. ex DC.) } 0 \\
\quad \text { Standley }\end{array}$ & 0.30 & $*$ & $*$ & $*$ & 0.18 & $* *$ & 2.75 & $*$ & $*$ & $*$ & 0.8 & $* *$ \\
\hline BURSERACEAE & & & & & & & & & & & & \\
\hline $\begin{array}{l}\text { Bursera leptophloeos (Mart.) Gillet. } \\
\text { CAESALPINIACEAE }\end{array}$ & $*$ & 5.88 & 9.60 & 7.78 & 10.0 & $* *$ & $*$ & 10.71 & 11.5 & 10.0 & 12.4 & ** \\
\hline Bauhinia cheilanta (Bong.) Steud. & $*$ & 4.61 & 0.27 & 2.72 & 0.66 & $* *$ & $*$ & 19.79 & 3.4 & 26.6 & 3.3 & $* *$ \\
\hline Caesalpinia ferrea Mart. ex Tul. & $*$ & $*$ & $*$ & $*$ & $*$ & $* *$ & $*$ & $*$ & $*$ & $*$ & $*$ & $* *$ \\
\hline C. pyramidalis Tul. & $*$ & 15.91 & 40.41 & 11.55 & 33.09 & $* *$ & $*$ & 35.01 & 103.6 & 32.4 & 97.1 & $* *$ \\
\hline $\begin{array}{l}\text { Hymenaea courbaril L. } \\
\text { CAPPARACEAE }\end{array}$ & 2.58 & $*$ & $*$ & $*$ & $*$ & $* *$ & 3.19 & $*$ & $*$ & $*$ & $*$ & $* *$ \\
\hline $\begin{array}{l}\text { Capparis flexuosa (L.) L. } \\
\text { CELASTRACEAE }\end{array}$ & $*$ & 0.91 & $*$ & $*$ & $*$ & $* *$ & $*$ & 4.86 & $*$ & $*$ & $*$ & $* *$ \\
\hline $\begin{array}{l}\text { Maytenus rigida } \text { Mart. } \\
\text { EUPHORBIACEAE }\end{array}$ & 0.26 & 0.07 & $*$ & $*$ & $*$ & $* *$ & 1.48 & 0.63 & $*$ & $*$ & $*$ & $* *$ \\
\hline Euphorbia tirucalli L. & $*$ & $*$ & $*$ & $*$ & $*$ & $* *$ & $*$ & $*$ & $*$ & $*$ & $*$ & $* *$ \\
\hline $\begin{array}{l}\text { Jatropha mollissima (Pohl) Baill } \\
\text { FABACEAE }\end{array}$ & $*$ & 0.12 & 0.82 & 2.34 & 1.04 & $* *$ & $*$ & 1.72 & 8.0 & 16.3 & 12.1 & $* *$ \\
\hline $\begin{array}{l}\text { Amburana cearensis (Allemão) A.C. Sm. } \\
\text { MELIACEAE }\end{array}$ & 1. * & $*$ & $*$ & $*$ & 1.48 & $* *$ & $*$ & $*$ & $*$ & $*$ & 5.7 & $* *$ \\
\hline $\begin{array}{l}\text { Cedrela odorata L. } \\
\text { MIMOSACEAE }\end{array}$ & $*$ & 0.54 & $*$ & $*$ & $*$ & $* *$ & $*$ & 0.78 & $*$ & $*$ & $*$ & ** \\
\hline $\begin{array}{l}\text { Anadenanthera colubrina (Vell.) Brenan. } \\
\text { var. cebil (Griseb.) Altschul. }\end{array}$ & $*$ & 8.90 & 3.44 & 5.86 & 11.32 & $* *$ & $*$ & 14.34 & 5.3 & 7.6 & 17.4 & ** \\
\hline Mimosa malacocentra Mart. & $*$ & 2.66 & $*$ & $*$ & $*$ & $* *$ & $*$ & 13.83 & $*$ & $*$ & $*$ & $* *$ \\
\hline M. tenuiflora (Willd.) Poir. & $*$ & $*$ & $*$ & $*$ & $*$ & $* *$ & $*$ & $*$ & $*$ & $*$ & $*$ & ** \\
\hline $\begin{array}{l}\text { Piptadenia stipulacea (Benth.) Ducke. } \\
\text { RHAMNACEAE }\end{array}$ & $*$ & 2.48 & $*$ & $*$ & $*$ & $* *$ & $*$ & 10.72 & $*$ & $*$ & $*$ & $* *$ \\
\hline $\begin{array}{l}\text { Ziziphus joazeiro Mart. } \\
\text { SAPOTACEAE }\end{array}$ & 3.08 & 0.10 & $*$ & $*$ & $*$ & $* *$ & 3.69 & 0.58 & $*$ & $*$ & $*$ & $* *$ \\
\hline $\begin{array}{l}\text { Sideroxylon obtusifolium (Roem. \& } \\
\text { Schult.) T.D. Penn. }\end{array}$ & $*$ & $*$ & $*$ & $*$ & $*$ & $* *$ & $*$ & $*$ & $*$ & $*$ & $*$ & $* *$ \\
\hline
\end{tabular}




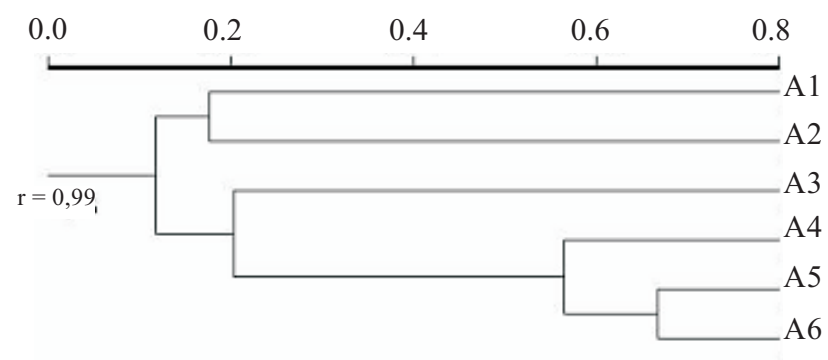

Figure 2. Dendrogram performed on Jaccard similarity matrix (presence-absence data) of six areas of caating a considering only the woody medicinal species (22). A1 (Buíque), A2 (Caruaru), A3 (Poço do Ferro, municipality of Floresta), A4 (Baixa do Faveleiro, municipality of Floresta), A5 (Samambaia, municipality of Custódia), and A6 (Ibimirim).

From the 22 species known to have medicinal use, Myracrodruon urundeuva (Engl.) and Schinopsis brasiliensis, both from family Anacardiaceae, are part of IBAMA's (Brazilian Institute of the Environment and of the Renewable Natural Resources) list of species threatened by extinction, under the "vulnerable" category. These two species grow very slowly and have been exploited continuously for local use (Sampaio 1995; Albuquerque et al. 2005). Undoubtedly, this selective elimination affects the vegetation's composition, but the effects have not been documented (Sampaio 1995). According to the classification of Almeida \& Albuquerque (2002), a vulnerable species is one that suffers systematic persecution, and is also very popular. In addition, the author verified that several other species are widely distributed, but with reduced populations. IBAMA's ordinance no. 83-N, of 09.26.91 regulates the prohibition of the cutting down of Myracrodruon urundeuva, which is a high priority species for germoplasm collection and conservation (Vieira 1999). Prohibiting the cutting down of species threatened by extinction is not an efficient alternative to guarantee their conservation; sustainable management techniques that enable economic return must be developed.

Several authors mention important aspects about the conservation of woody arboreal species with economic and medicinal relevance. According to Reis (1996), medicinal species must not be considered solely as a therapeutic resource, but also as a source of economic resources; thus, it is necessary to establish strategies for developing techniques of sustainable management, allied to the maintenance of the equilibrium of tropical ecosystems. Silva et al. (1987), in a commentary about the conservation of genetic resources, says that in addition to in situ ecological
Table 5. Relative Importance of the medicinal species of six areas of caatinga in the state of Pernambuco. NSC $=$ Number of Corporeal Systems treated by species; $\mathrm{NP}=$ Number of Properties of the species; RI = Relative Importance of the species.

\begin{tabular}{|c|c|c|c|}
\hline Species & NCS & NP & RI \\
\hline \multicolumn{4}{|l|}{ ANACARDIACEAE } \\
\hline Anacardium occidentale L. & 1.00 & 1.00 & 2.00 \\
\hline Myracrodruon urundeuva (Engl.) Fr. All. & 0.57 & 0.53 & 1.10 \\
\hline Schinopsis brasiliensis Engl. & 0.71 & 0.53 & 1.24 \\
\hline \multicolumn{4}{|l|}{ BIGNONIACEAE } \\
\hline $\begin{array}{l}\text { Tabebuia impetiginosa (Mart. ex DC.) } \\
\text { Standley }\end{array}$ & 1.00 & 0.92 & 1.92 \\
\hline \multicolumn{4}{|l|}{ BURSERACEAE } \\
\hline $\begin{array}{l}\text { Bursera leptophloeos (Mart.) Gillet. } \\
\text { CAESALPINIACEAE }\end{array}$ & 0.57 & 0.38 & 0.95 \\
\hline Bauhinia cheilanta (Bong.) Steud. & 0.42 & 0.23 & 0.65 \\
\hline Caesalpinia ferrea $\mathrm{Ma}$ & 0.57 & 0.38 & 0.95 \\
\hline C. pyramidalis Tul. & 0.28 & 0.23 & 0.51 \\
\hline Hymenaea courbaril L. & 0.28 & 0.30 & 0.58 \\
\hline \multicolumn{4}{|l|}{ CAPPARACEAE } \\
\hline Capparis flexuosa (L.) L. & 0.14 & 0.076 & 0.21 \\
\hline \multicolumn{4}{|l|}{ CELASTRACEAE } \\
\hline Maytenus rigida Mart. & 0.42 & 0.23 & 0.65 \\
\hline \multicolumn{4}{|l|}{ EUPHORBIACEAE } \\
\hline Euphorbia tirucalli L. & 0.28 & 0.23 & 0.51 \\
\hline Jatropha mollissima (Pohl) Baill & 0.14 & 0.076 & 0.21 \\
\hline \multicolumn{4}{|l|}{ FABACEAE } \\
\hline Amburana cearensis (Allemão) A.C. Sm. & 0.28 & 0.38 & 0.66 \\
\hline \multicolumn{4}{|l|}{ MIMOSACEAE } \\
\hline $\begin{array}{l}\text { Anadenanthera colubrina (Vell.) Brenan. } \\
\text { var. cebil (Griseb.) Altschul. }\end{array}$ & 0.57 & 0.38 & 0.95 \\
\hline Mimosa malacocentra Mart. & 0.28 & 0.15 & 0.43 \\
\hline M. tenuiflora (Willd.) Poir. & 0.28 & 0.15 & 0.43 \\
\hline Piptadenia stipulacea (Benth.) Ducke. & 0.14 & 0.076 & 0.21 \\
\hline RHAMNACEAE & & & \\
\hline Ziziphus joazeiro Mart. & 0.42 & 0.38 & 0.80 \\
\hline SAPOTACEAE & & & \\
\hline $\begin{array}{l}\text { Sideroxylon obtusifolium (Roem. \& } \\
\text { Schult.) T.D. Penn. }\end{array}$ & 0.28 & 0.23 & 0.51 \\
\hline
\end{tabular}

reserves of ecologically and/or economically important populations of individuals such as Myracrodruon urundeuva, ex situ reserves must be established to guarantee the perpetuation of genetic resources.

To establish the conservation of woody medicinal species in the caatinga, and for the efficient development of sustainable management techniques, it is necessary to analyze the particularities of each region, from the perspective of each of their total and medicinal arboreal flora, as well as the species with conservation priorities. According to Silva et al. (1987), these species belong to families with few genera and are widely used in popular medicine; therefore, they are more vulnerable than the more abundant species and than those from large families. 
Despite the fact that its area occupies $11.67 \%$ of the national territory, in relation to the conservation of plant resources of the caatinga, only $3.56 \%$ of the caatinga is located in the federal conservation units (16), and from these, $0.87 \%$ in indirect use units (national parks, biological reserves, and ecological stations, from which only seven are at state level - in the states of Bahia and Rio Grande do Norte) (The Nature Conservancy do Brasil 2000). Only half of the federal units are composed exclusively of caatinga; from these, have are of direct use and half of indirect use. In Pernambuco there is only one of these conservation units, located in the Biological Reserve of Serra Negra, with an area of 1,100 ha; the brejo is the predominant type of vegetation and the caatinga (ecotone) occupies $40 \%$ of the area, according to data from The Nature Conservancy do Brasil (2000). The role of the Private Reservations of Natural Patrimony (Reservas Particulares do Patrimônio Natural RPPN's) is also important for the conservation of the caatinga, but in Pernambuco there is only one, located in the Ecological reserve of Maurício Dantas, with an area of $1,485 \mathrm{ha}$; there, activities of recuperation of degraded areas, environmental education, and apiculture are undertaken (The Nature Conservancy do Brasil 2000).

Finally, the results presented here suggest that: the woody medicinal flora of the caatinga can be the result of selective management by local populations, in face of the apparent specificity of the analyzed areas; yet, systematic studies related to this aspect are necessary; a species with high values of Density and Relative Frequency is not, necessarily, the most important from a medicinal point of view; there is correlation between a species' Relative Importance and some phytosociological parameters.

\section{References}

Agra, M.F. 1996. Plantas da medicina popular dos Cariris Velhos, Paraíba, Brasil. João Pessoa, Editora União.

Agra, M.F. 1999. Plantas medicinais dos Cariris Velhos, Paraíba: um projeto interdisciplinar. Pp. 16-21. In: F.D. de Araújo; H.D.V. Prendergast \& S.J. Mayo (eds.). Plantas do Nordeste. Anais do I Workshop Geral. Kew, Royal Botanic Gardens.

Albuquerque, U.P.; Silva, A.C.O. \& Andrade, L.H.C. 2005. Use of planta resources in a seasonal dry forest (northeastern Brazil). Acta Botanica Brasilica 19: 27-38.

Albuquerque, U.P. \& Andrade, L.H.C. 2002a. Uso de recursos vegetais da caatinga: o caso do agreste do estado de Pernambuco (Nordeste do Brasil). Interciencia 26(7): 336-346.
Albuquerque, U.P. \& Andrade, U.P. 2002b. Conhecimento botânico tradicional e conservação em uma área de caatinga no estado de Pernambuco, Nordeste do Brasil. Acta Botanica Brasilica 16(3): 273-285.

Almeida, C.F.C.B. \& Albuquerque, U.P. 2002. Uso e conservação de plantas e animais medicinais no estado de Pernambuco (Nordeste do Brasil): um estudo de caso. Interciencia 26(6): 276-285.

Alcoforado-Filho, F.G.; Sampaio, E.V.S.B. \& Rodal, M.J.N. 2003. Florística e fitossociologia de um remanescente de vegetação caducifólia espinhosa arbórea em Caruaru, Pernambuco. Acta Botanica Brasilica 17: 287-303.

Andrade-Lima, D. 1981. The caatinga dominium. Revista Brasileira de Botânica 4: 149-153

Araújo, E.L.; Sampaio, E.V.S.B. \& Rodal, M.J.N. 1995. Composição florística e fitossociologia de três áreas de Caatinga de Pernambuco. Revista Brasileira de Biologia 55: 595-607.

Balée, W. 1988. Cultural Forests of the Amazon. Garden 32: $12-14$.

Bennett, B.C. \& Prance, G.T. 2000. Introduced plants in the indigenous pharmacopoeia of Northern South America. Economic Botany 54: 90-102.

Braga, R. 1960. Plantas do Nordeste, especialmente do Ceará. Fortaleza, Ceará.

Di Stasi, L.C.; Santos, E.M.G.; Santos, C.M. \& Hiruma, C.A. 1989. Plantas medicinais na Amazônia. São Paulo, Ed. Universidade Estadual Paulista.

Ferri, M.G. 1980. Vegetação brasileira. São Paulo, Ed. da Universidade de São Paulo.

Figueirêdo, L.S.; Rodal, M.J.N. \& Melo, A.L. 2000. Florística e fitossociologia de uma área de vegetação arbustiva caducifólia espinhosa no município de Buíque Pernambuco. Naturalia 25: 205-224.

Gomes, A.P.S. 1999. Florística e fitossociologia de uma vegetação arbustiva subcaducifólia no município de Buíque - Pernambuco. Dissertação de Mestrado. Universidade Federal Rural de Pernambuco, Recife.

Hueck, K. 1972. As florestas da América do Sul: ecologia, composição e importância econômica. São Paulo/ Brasília, Polígono/ Ed. da Universidade de Brasília.

Lima, J.L.S. 1999. Levantamento fitoecológico do Município de Petrolina - PE. Pp. 33-41. In: F.D. de Araújo; H.D.V. Prendergast \& S.J. Mayo (eds.). Plantas do Nordeste. Anais do I Workshop Geral. Kew, Royal Botanic Gardens.

Oliveira, M.E.A.; Sampaio, E.V.S.B.; Castro, A.A.J. \& Rodal, M.J.N. 1997. Flora e fitossociologia de uma área de transição carrasco-caatinga de areia em Padre Marcos, Piauí. Naturalia 22: 131-150.

Philips, O. \& Gentry, A.H. 1993. The useful plants in Tambopata, Peru: I. Statistical hypothesis tests with a new quantitative technique. Economic Botany 47: 15-32.

Reis, M.S. 1996. Manejo sustentado de plantas em ecossistemas tropicais.Pp. 199-215. In: L.C. Di Stasi (org.). Plantas medicinais: arte e ciência - um guia de estudo interdisciplinar. São Paulo, Editora da UNESP. 
Rodal, M.J.N.; Andrade, K.V.S.A.; Sales, M.F. \& Gomes, A.P.S. 1998. Fitossociologia do componente lenhoso de um refúgio vegetacional no município de Buíque, Pernambuco. Revista Brasileira de Biologia 58: 517-526.

Rodal, M.J.N. \& Melo, A.L. 1999. Levantamento preliminar das espécies lenhosas da caatinga de Pernambuco. Pp. 53-62. In: F.D. de Araújo; H.D.V. Prendergast \& S.J. Mayo (eds.). Plantas do Nordeste. Anais do I Workshop Geral. Kew, Royal Botanic Gardens.

Rodal, M.J.N.; Nascimento, L.M. \& Melo, A.L. 1999. Composição florística de um trecho de vegetação arbustiva caducifólia no município de Ibimirim, PE, Brasil. Acta Botanica Brasilica 13: 15-28.
Rohlf, J. 1993. Numerical taxonomy and multivariate analyses system for the IBM PC microcomputer (and compatibles). Version 1.8. New York, Applied Biostatistics Inc.

Sampaio, E.V.S.B. 1995. Overview of the Brazilian Caatinga. Pp. 35-63. In: S. Bulock (org.). Seasonally dry Tropical Forests. Cambridge, University Press.

Silva, J.A.; Leite, E.J. \& Gripp, A. 1986/1987. Estratégia para conservação genética de espécies florestais prioritárias na Amazônia. Acta Amazonica 16/17: 535-548.

The Nature Conservancy do Brasil. 2000. Unidades de Conservação na caatinga. Petrolina, Pernambuco.

Vieira, R.F. 1999. Conservation of medicinal and aromatic plants in Brazil. Pp. 152-159. In: J. Janick. New Crops and New Uses: Biodiversity and Agricultural Sustainability. ASHS Press, Alexandria, VA. 